\title{
Role of Mycoplasma Chaperone DnaK in Cellular Transformation
}

\author{
Francesca Benedetti ${ }^{1,2}$, Fiorenza Cocchi ${ }^{1,3}$, Olga S. Latinovic ${ }^{1,4}$, Sabrina Curreli ${ }^{1,4}$, \\ Selvi Krishnan ${ }^{1}$, Arshi Munawwar ${ }^{1}$, Robert C. Gallo ${ }^{1,3}$ and Davide Zella 1,2,*iD \\ 1 Institute of Human Virology, School of Medicine, University of Maryland, Baltimore, MD 21201, USA; \\ fbenedetti@ihv.umaryland.edu (F.B.); fcocchi@ihv.umaryland.edu (F.C.); \\ olatinovic@ihv.umaryland.edu (O.S.L.); SCurreli@ihv.umaryland.edu (S.C.); \\ skrishnan@ihv.umaryland.edu (S.K.); amunawwar@ihv.umaryland.edu (A.M.); \\ rgallo@ihv.umaryland.edu (R.C.G.) \\ 2 Department of Biochemistry and Molecular Biology, School of Medicine, University of Maryland, \\ Baltimore, MD 21201, USA \\ 3 Department of Medicine, School of Medicine, University of Maryland, Baltimore, MD 21201, USA \\ 4 Department of Microbiology and Immunology, School of Medicine, University of Maryland, \\ Baltimore, MD 21201, USA \\ * Correspondence: dzella@ihv.umaryland.edu
}

Received: 16 January 2020; Accepted: 12 February 2020; Published: 15 February 2020

\begin{abstract}
Studies of the human microbiome have elucidated an array of complex interactions between prokaryotes and their hosts. However, precise bacterial pathogen-cancer relationships remain largely elusive, although several bacteria, particularly those establishing persistent intra-cellular infections, like mycoplasmas, can alter host cell cycles, affect apoptotic pathways, and stimulate the production of inflammatory substances linked to DNA damage, thus potentially promoting abnormal cell growth and transformation. Consistent with this idea, in vivo experiments in several chemically induced or genetically deficient mouse models showed that germ-free conditions reduce colonic tumor formation. We demonstrate that mycoplasma DnaK, a chaperone protein belonging to the Heath shock protein (Hsp)-70 family, binds Poly-(ADP-ribose) Polymerase (PARP)-1, a protein that plays a critical role in the pathways involved in recognition of DNA damage and repair, and reduces its catalytic activity. It also binds USP10, a key p53 regulator, reducing p53 stability and anti-cancer functions. Finally, we showed that bystander, uninfected cells take up exogenous DnaK—suggesting a possible paracrine function in promoting cellular transformation, over and above direct mycoplasma infection. We propose that mycoplasmas, and perhaps certain other bacteria with closely related DnaK, may have oncogenic activity, mediated through the inhibition of DNA repair and p53 functions, and may be involved in the initiation of some cancers but not necessarily involved nor necessarily even be present in later stages.
\end{abstract}

Keywords: Mycoplasma; DnaK; cancer; p53; microbiota

\section{Mycoplasma}

Mycoplasmas are the smallest and simplest self-replicating bacteria, ranging from 0.1 to $0.3 \mu \mathrm{m}$ in diameter and up to $200 \mu \mathrm{m}$ in length. The mycoplasma cell contains the essential organelles needed for growth and replication: plasma membrane, ribosomes, and a genome consisting of a double-stranded circular DNA molecule. Unlike all other prokaryotes, the mycoplasmas have no cell walls, and they are consequently placed in the Mollicutes class (mollis= soft; cutis=skin) [1]. The plasma membrane is composed of approximately two-thirds protein and one-third lipid. Membrane proteins, glycolipids and lipoglycans exposed on the cell surface are the major antigenic determinants in mycoplasmas [2-5]. 
Mycoplasma species are widespread in nature: they are parasites of humans, animals, plants and arthropods. They usually exhibit organ and tissue specificity, and their primary localizations are the mucous surface of the respiratory and urogenital tracts, the eyes, the alimentary canal, the mammary glands and the joints [6]. Besides residing in contact with the cellular membrane, some mycoplasma species can invade the cells and become intracellular residents $[7,8]$. Because mycoplasmas lack cell walls, they can invade the host cells by interacting with the membrane of the host and fuse together the two membranes. Membrane fusion alters the composition and permeability of the host cell membrane and enable the introduction of the mycoplasma's hydrolytic enzymes into the host cell, causing severe damages $[9,10]$.

Although some mycoplasmas belong to the normal microbiota, many species are pathogens that can cause various diseases either asymptomatic or chronic. Seven species of mycoplasma (M. pneumoniae, M. urealyticum, M. genitalium, M. hominis, M. fermentans, M. penetrans and M. pirum) are mainly related to human pathologies, such as acute respiratory illness, genitourinary tract infections, joint infections and neurologic disorders [11-16]. In fact, mycoplasmas can elicit strong host immune responses due to the presence of lipoproteins on their membrane able to trigger a Toll-like receptor-mediated response, activate macrophages, induce cytokine production and lymphocyte proliferation [17-20]. Furthermore, because of the presence of antigenic variability systems, mycoplasmas are able to rapidly change the composition of the major surface protein antigens and consequently escape recognition by the immune mechanisms of the host [21-23].

\section{Mycoplasma and COPD}

Chronic Obstructive Pulmonary Disease (COPD) is the third leading cause of death in the United States, with more than 130,000 deaths annually. Worldwide, more than 3 million people die annually of COPD, mostly in middle- and low-income regions. Almost 15 million people have been diagnosed with COPD in the US alone, but millions more may have the disease without even knowing it. COPD causes serious long-term disability and early death. At this point, there is no cure, and the number of people dying from COPD is growing. The main cause of COPD in developed countries is smoking [24], while in developing countries COPD is also frequently seen in patients exposed to environmental air-polluting agents (for example burning fuel for cooking). COPD is characterized by chronic inflammation leading to progressive lung damage, which ultimately contributes to irreversible airflow obstruction [25]. An acute exacerbation of COPD is defined as increased shortness of breath and sputum production, a change in the color of the sputum from clear to green or yellow, or an increase in cough. Furthermore, the oxidant burden in the lungs of COPD patients, caused by an imbalance between the generation of free radicals and the antioxidant defense systems, increases the release of multiple inflammatory mediators with further reduction in responsiveness during anti-inflammatory treatments [26]. Dysbiosis is observed in lungs of patients of COPD, in that the composition of lungs microbiota is less diverse than the one observed in healthy persons, and has a tendency to be restricted to phyla comprising potentially pathogenic microorganism, including M. pneumoniae $[24,27,28]$, also associated with acute exacerbation [29,30]. Some of the mechanisms by which M. pneumoniae could enhance the negative effects of tobacco products in COPD patients is by increasing oxidative stress [31], inflammation status and hypoxia-related factors, such as HIF-1 $\alpha$ [32]. Quitting smoking in combination with anti-muscarinic bronchodilators resulted in an improvement of lung function and respiratory symptoms in mild COPD patients and it could be interesting to determine whether this would also result in a reduction in dysbiosis and the presence of M. pneumoniae [24]. An increased risk of developing lung cancer was observed in smokers with airflow obstructions, particularly of squamous histological subtype in patients diagnosed with non-small cell lung carcinoma, compared to smokers with normal lung functions [33-35], and it has been shown a prognostic effect of hypoxia (measured through expression of HIF-1 $\alpha$ ) with COPD and lung cancer [36]. 


\section{Mycoplasma and Cancer}

Mycoplasmas are part of the human microbiota: they are commensals, but they have also been associated with tumorigenesis. The correlation between mycoplasmas and cancer remains unclear [37,38], but epidemiological studies, in vitro experiments and genome sequence analysis indicate a close involvement of mycoplasmas in cellular transformation and cancer progression [39].

Several studies in vitro using bronchial epithelial cells [40], hepatocytes [41], oral tissues [42], human prostate cells $[43,44]$ and cervical cells [45] indicate that the presence of mycoplasma may facilitate tumorigenesis by promoting cellular transformation [46,47]. In addition, experimental data indicates that mycoplasmas infection cause chromosomal changes, instability and cell transformations in vitro through progressive chromosomal loss and translocations [45,48-50]. It has been demonstrated that M. fermentans, M. penetrans and M. hyorhinis are able to induce the accumulation of chromosomal abnormalities and also phenotypic changes of the transformed cells $[45,49,50]$. In more detail-during the long-term infection of mouse embryo fibroblasts with M. fermentans or M. penetrans spontaneous cellular transformation and overexpression of the H-Ras and c-myc proto-oncogenes have been shown [51]. Infection with M. fermentans, arginini and hominis reduced the activity of p53 and induced the constitutive activation of the NF- $\mathrm{KB}$ transcription factor in mouse 3T3 cells [52]. The incorrect regulation of NF- $\mathrm{kB}$ has been in fact linked to cancer, inflammatory and autoimmune diseases, viral infection, and improper immune development [17,53-55]. Aberrant DNA methylation has also been observed in cancer [56]. M. hyorhinis encodes DNA-(cytosine-5)-methyltransferase enzymes that target CpG dinucleotides, establishing the methylation patterns of the bacterial genomes [57]. When expressed in human cells, they are able to translocate into the nucleus and create abnormal methylation patterns of the host cell DNA [57-61]. These epigenetics changes can contribute and lead to cancer progression by stimulating pro-oncogenic pathways. M. fermentans, M. hominis and M. penetrans have also been shown to cause the transformation of human lung cells and mouse myeloid cells and fibroblasts by inducing the bone morphogenetic protein 2 (BMP-2) [62], that is considered a marker for lung cancer when highly expressed and is also associated with poor patient survival [63].

More recently, it has been shown that M. hyorhinis induces the motility of gastric cancer cells by activating the Wnt/ßcatenin signaling pathway through the membrane protein p37 [64], that has also been shown to significantly correlate with high vascular invasion and associated with poor disease-free survival of Hepatocellular carcinoma patients. In vitro studies suggest that $\mathrm{M}$ hyorhinis infection promotes tumor progression in HCC patients, by increasing the migratory capacity of HCC cells, through the interaction of p37 with epithelial cell adhesion molecule (EpCAM) [65]. The p37 protein alone may be considered sufficient to increase invasiveness and metastases of different cancer cells $[41,66,67]$.

Many in vitro studies support the ability of some mycoplasmas to induce cancer transformation and many pro-cancer mechanisms have been investigated in the last years: from the induction of genetic instability $[48,49]$, to alterations in metabolism [68] and changes in the expression of tumor suppressor or oncogenes $[46,51,52,69]$. However, no carcinogenic roles for any mycoplasma have been demonstrated in vivo. Several specimens from patients (infectious tissues, neoplastic tissues and body fluids) have been analyzed and mycoplasma has been isolated and detected in those samples without any formal demonstration of causality. In particular, mycoplasmas have been detected so far in many tumor tissues (precancerous lesions and malignant tissues) from patients with gastric, esophageal, colon, lung, breast, glioma, renal, ovarian, cervical and prostate cancers [67,70-73].

\section{Bacterial DnaK}

To cope with different stressful conditions and maintain the proper proteostasis, eukaryotic organisms have a redundant system of chaperone proteins [74]. One of these families (Hsp70) is comprised of slightly different proteins [75], and the over-expression of some members of the Hsp70 family increases the transformation of several human cell types $[76,77]$. On the other hand, suppression of Hsp70 expression by anti-sense Hsp70 cDNA inhibits tumor cell proliferation and 
induces apoptosis [78]. Though with some differences in amino acid sequences among the several bacteria species, the bacterial chaperone system is mainly organized around the DnaK protein (corresponding to the eukaryotic Hsp70), thus representing a central hub in prokaryotic protein interaction networks [79].

Chaperone activity of Hsp70/DnaK is controlled by cycles of ATP binding and hydrolysis [80]. DnaK itself is a weak ATPase, while direct interaction with the co-chaperone DNAJ proteins (members of the HSP40 family) [81,82] greatly increases ATPase activity, promotes binding with target proteins and accelerates protein-folding activity of Hsp70/DnaK [83]. There are three types of co-chaperone proteins comprising the DNAJ family: DNAJA (type I), DNAJB (type II) and DNAJC (type III) based on the presence or absence of conserved domains defined by the canonical DNAJ of E. coli [84]. It has been shown that specific DNAJ may play an important role in influencing cancer development and spread, possibly due to their role as co-chaperones influencing folding of various oncogenes or tumor suppressors [85-102].

\section{Mycoplasma DnaK Interferes with Important Anti-cancer Cellular Pathways and Is Taken up by Bystander Cells.}

We isolated and characterized a strain of human M. fermentans (MF-I) able to induce lymphoma in a Severe Combined Immuno-Deficient (SCID) mouse model [103-105], similar to a previously described lymphomagenesis dependent upon reduced p53 activity [106]. Mycoplasma was abundantly detected early in infected mice, but only low copy numbers of mycoplasma DnaK DNA sequences were found in primary and secondary tumors, suggesting a "hit and run/hide" mechanism of transformation, in which the critical events have occurred previous to cancer detection [107]. We demonstrated that this mycoplasma's DnaK binds to human USP10 (ubiquitin carboxyl-terminal hydrolase 10, a regulator of p53 stability), reducing p53 stability and anti-cancer functions, potentially increasing the likelihood of DNA mutations and consequent malignant transformation [107]. P53 is a major tumor suppressor, often called "the guardian of the genome" for its multiple anti-oncogenic activities. By tightly coordinating cell cycle and apoptotic responses, p53 ensures that DNA damage is properly repaired, or that the damaged cell is removed upon engagement of the apoptotic pathway. P53 is mutated in about $50 \%$ of human cancers [108-110], and a mutated p53 allele can lead to Li-Fraumeni syndrome, characterized by development of several types of cancers [111]. In animal models, p53-/- mice develop cancers (mainly lymphomas and sarcomas) with nearly 100\% penetrance [112]. Several proteins regulate p53, of which USP10 (ubiquitin carboxyl-terminal hydrolase protein-10) is one of the most important. By removing conjugated ubiquitin from target proteins, including p53, USP10 increases p53 stability in unstressed cells. This process is very important during DNA-damage response, in which USP10 translocates to the nucleus and deubiquitinates p53, stabilizing it and thus regulating its response to DNA damage [113-115]. It is thus clear that the reduction in USP10 activity caused by mycoplasma DnaK can have profound negative effects on the anti-cancer functions of p53.

In addition, we show that mycoplasma DnaK reduced PARylation activity of PARP1 following DNA damage (Figure 1). PARP 1 is one of the most studied members of the family of PARP proteins [116]. PARP1 is involved in the recognition and subsequent repair of single and double-strand breaks in DNA [117-119]. Following interaction with forms of damaged DNA, PARP1 activity is increased dramatically, resulting in PARylation of several proteins, including itself, histones, topoisomerase 1 (TOP1), DNA-dependent protein kinase (DNA-PK) and others [120], and in recruitment of single-strand break repair (SSBR)/base-excision repair (BER) factors to the damaged site [121]. Failure to properly repair DNA damage usually results in apoptosis, thus avoiding accumulation of DNA damage that could ultimately lead to cellular transformation. Mice lacking PARP1 exhibit high levels of sister chromatid exchange [122,123], increased chromosomal aberrations, including fusions, breaks, and telomere shortening [124], and double-mutant DNA-PK/PARP1-deficient mice develop a high frequency of T-cell lymphomas [125]. Following transfection with an expression vector carrying MF-I1 DnaK under the CMV promoter (see also [107], cells were treated at different time-points with $\mathrm{H}_{2} \mathrm{O}_{2}$, which 
causes DNA damage and promotes an increase in PARP activity. Protein PARylation appears as a smear of variable intensity, which in turn depends on the activity of PARP. We measured PARylation of proteins $>150 \mathrm{KDa}$ molecular weight (MW), and between 100 and $150 \mathrm{KDa}$ and we observed two distinct patterns of PARylation in transfected cells. As represented in Fig 1B (left), PARylation of proteins $>150 \mathrm{KDa}$ in the control, the not-transfected cells reached a peak at 20 min post-treatment, and then rapidly decreased. This peak was high and delayed in cells transfected with the empty vector, indicating an effect of the transfection procedure, of the vector, or both. However, in the presence of the vector expressing MF-DnaK, PARylation of proteins $>150$ KDa MW was effectively abrogated (Figure 1B left). We observed a less pronounced difference in the PARylation of proteins between 100-150 KDa in cells transfected with the empty vector compared with the vector expressing MF-I1 DnaK (Figure 1B, right). Our data would indicate that the presence of DnaK greatly reduces the PARylation of certain proteins of very high MW (>150 KDa), while it seems to only marginally affect the PARylation of proteins between 100-150 KDa. This WB-based assay did not allow us to measure the PARylation of proteins $<100 \mathrm{KDa}$, even though we previously demonstrated a reduction in histones PARylation in an in vitro assay [107]. We are currently investigating the underlying molecular mechanisms of this reduction and its relevance in vivo.

(A)

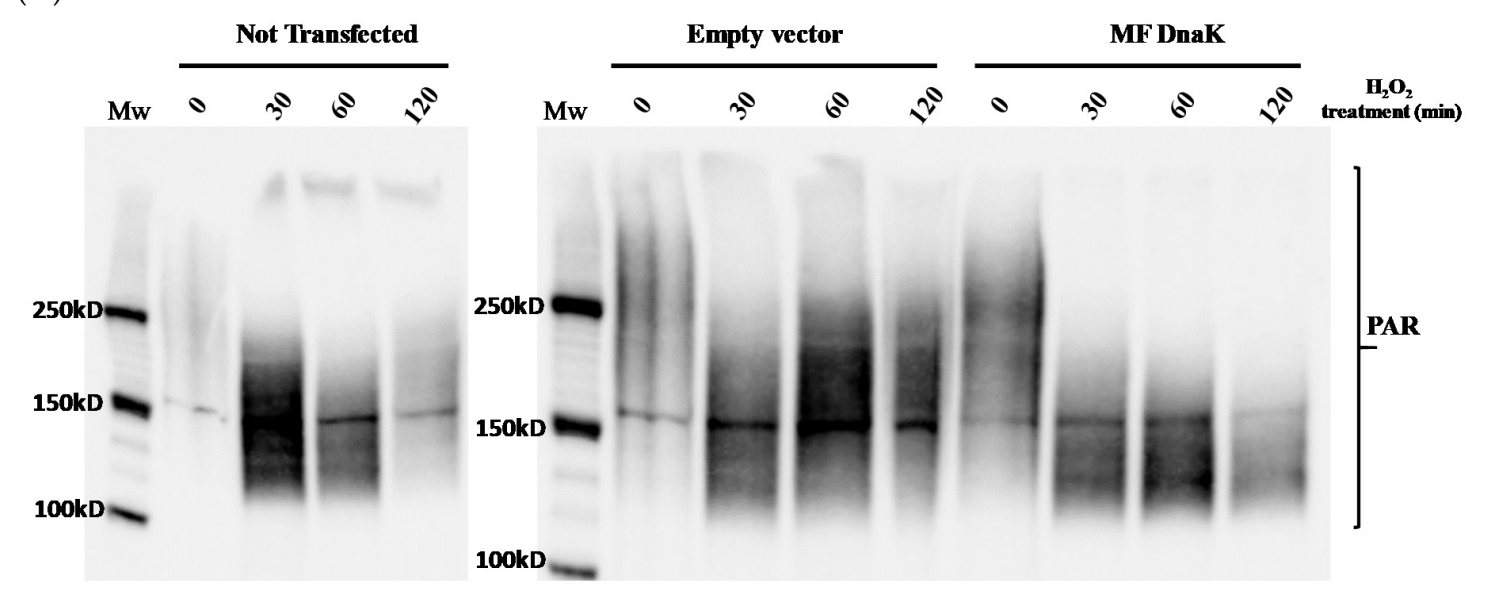

(B)

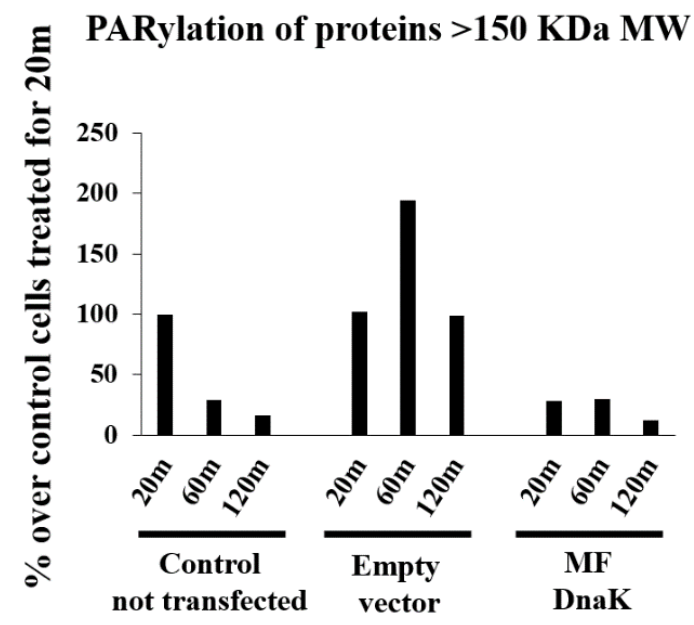

PARylation of proteins < 150 KDa MW

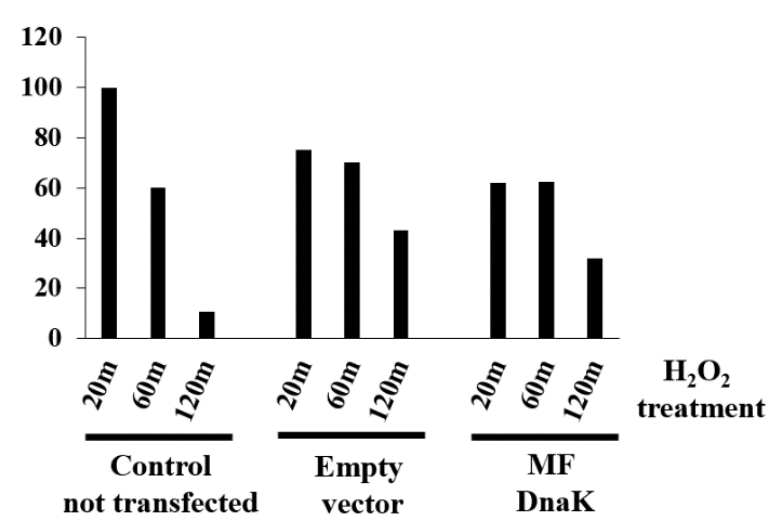

Figure 1. DnaK reduces PARylation in HCT116 cells. Following transfection, HCT116 cells were treated with $\mathrm{H}_{2} \mathrm{O}_{2}$ and collected at the indicated time points. Cells lysates were then subjected to SDS-PAGE $6 \%$ and protein parylation was detected by Western blot, using a specific anti-PAR antibody. MW are indicated. (A). Western blot analysis of HCT-116 cells. (B). Quantification of PARylated proteins. 
It should be noted that there are about $10^{6}$ PARP1 molecules [126-128] and about $10^{4}$ molecules of p53 per eukaryotic cell (http://book.bionumbers.org/what-are-the-concentrations-of-cytoskeletalmolecules/). On the other hand, the number of DnaK molecules measured in a single bacterial microorganism varies from $4 \times 10^{4}$ to $1 \times 10^{5}$, relative to its stress-induced status [129]. It thus appears that, under the proper stress-induced conditions, a single bacterium is able to produce enough DnaK molecules to severely affect the number of PARP1 and p53 molecules available to properly perform their DNA-repair and anti-cancer functions. For this reason, we believe that our data obtained by transfection experiments recapitulate what may be happening in vivo, i.e., that in cells where the DnaK is present, PARP1 and p53 activities will be reduced, increasing the likelihood of DNA instability and consequent malignant transformation.

Bacteria can translocate proteins into eukaryotic cells either by attaching to the outside of the cellular membrane or by invading the cell $[130,131]$. In addition, prokaryotic and eukaryotic membrane-localized Hsp70 proteins may be released into the surrounding microenvironment and then translocate into the cytoplasm of nearby cells [132-136]. Using confocal microscopy, we were able to visualize and demonstrate that bystander, uninfected cells take up exogenous DnaK, suggesting a possible paracrine function in promoting cellular transformation, over and above direct mycoplasma infection (Figure 2A, B). Insets present a 3D assembly of the exogenous DnaK uptake by PC3 and HeLa cells (Figure 2A,B). Through immunoprecipitation studies, we previously demonstrated that mycoplasma DnaK is able to bind human DNAJ1A1 [107]. This could indeed indicate that, once in the intracellular compartments-either because released by invading bacteria or taken up by uninfected cells-some bacterial DnaKs may become functionally active by binding to the cellular co-chaperone DNAJA1. It is not clear at the moment what may be the extent of this exploitation, i.e., whether other DnaKs have the same ability, or whether other co-chaperones may be involved.

Phylogenetic analysis showed that certain mycoplasmas, H. pylori and F. nucleatum have closely related DnaKs [107]. Definitive establishment of the causal correlation between H. pylori and gastric cancer provided the first demonstration that bacteria can cause cancer [137], and recent examples of studies in human patients highlighted an association between F. nucleatum and colorectal cancer [138-144]. Based on our data, it is tempting to speculate that a potential common mechanism could be involved in cellular transformation, where the DnaK of certain bacteria would interfere with pathways responsible for DNA repair and programmed cell death, with the consequent accumulation of mutations and a greatly increased chance of cellular transformation (Figure 3). However, additional experiments are still needed to support this hypothesis. 
Entry of exogenous DnaK into Prostate cancer cells (PC3)

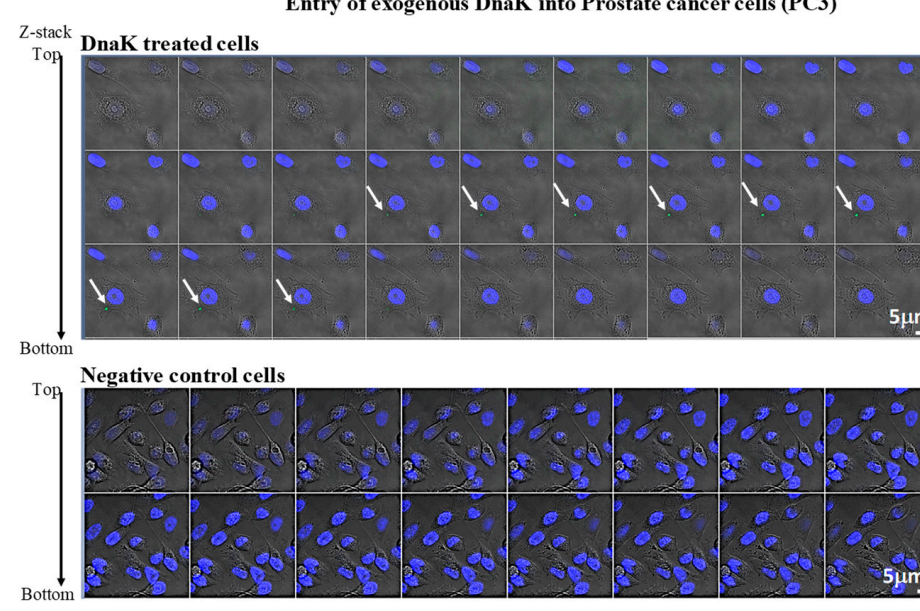

Entry of exogenous DnaK into Cervical cancer cells (HeLa)

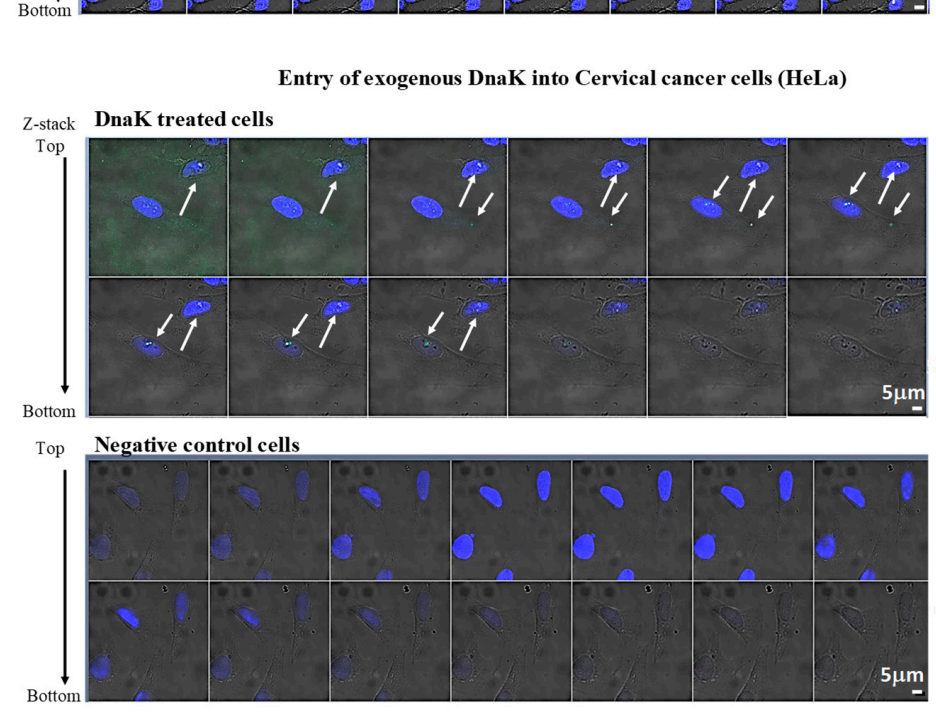

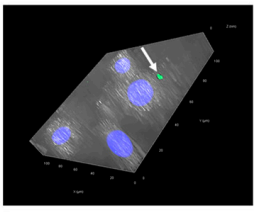

3D presentation

B

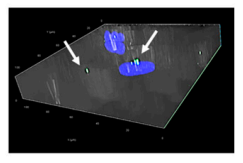

3D presentation

Figure 2. Intracellular uptake of exogenous DnaK-V5 by mycoplasma-free in PC-3 (A) and in HeLa cells (B). Confocal images of exogenous DnaK-V5 protein of M. fermentans in cells treated or not treated with DnaK-V5 protein. The figures show the collected Z-stacks of the corresponding gallery of images, each presenting a 0.5- $\mu \mathrm{m}$-thick slide. A mouse monoclonal antibody, anti-V5, was used for primary labeling, and a FITC fluoresce-labeled polyclonal rabbit anti-mouse antibody was used for secondary labeling. Arrows indicates protein localization. Negative control cells, treated with primary and secondary antibodies alone without DnaK-V5 protein, are represented at the bottom of each figure. Insets in the upper right corners of A and B show a corresponding constructed 3D presentation of the protein uptake. Materials and Method for Figure 2, we followed the protocol described in [66] to perform the experiments described. Cell lines were obtained from the ATCC. 
Oncogenesis limited to DNA damage*

- UV light exposure

- Ionizing radiation

- Chemical exposure

- Reactive Oxygen Species (ROS)

- Other DNA damaging agents

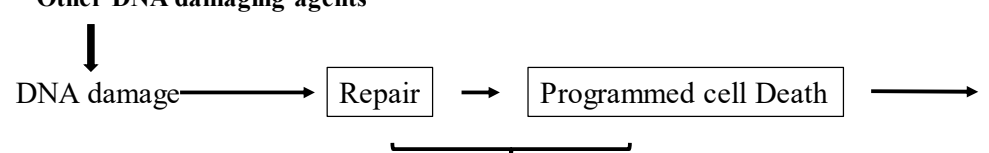

Decreased activity due to DnaKs of some bacteria (Mycoplasma, Fusobacterium, Helicobacter)

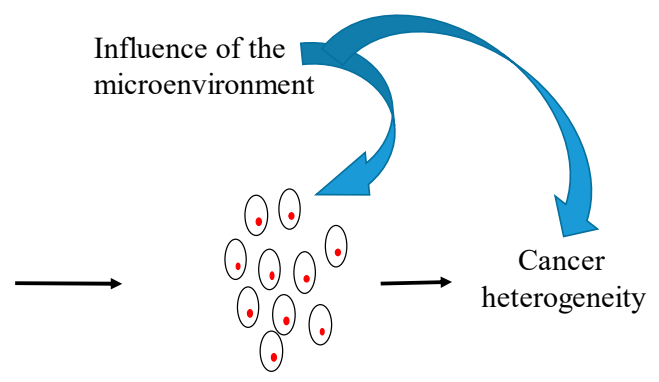

Neoplastic

transformation

\footnotetext{
Common in virtually all cancers

*: e.g., not including viruses
}

Figure 3. Some bacterial DnaKs may promote cellular transformation by affecting important cellular pathways.

\section{Conclusions}

Several different bacteria have been recently associated with the origin of some human cancers, particularly those capable of establishing persistent intracellular infection, affecting host cell cycles and apoptotic pathways, and stimulating the production of inflammatory substances linked to DNA damage, thus potentially promoting DNA mutations and abnormal cell growth. The specific mechanism(s) whereby bacteria transform host cells are poorly understood and precise pathogen-cancer relationships remain largely elusive, except in the case of H. pylori, where a direct causal link has been demonstrated and a p53-related molecular mechanism implicated in cellular transformation has been described $[137,145,146]$. Based on our data, we propose that mycoplasmas-and perhaps certain other bacteria with closely related DnaK sequences and structure-have oncogenic potential mediated through the DnaK-dependent inhibition of DNA repair mechanisms and p53 function. DnaK could act in concert with some external factors-like smoking-previously shown to hamper the p53-p21 axis-dependent pathways [147]. The presence of some DnaKs would thus prevent the proper coordinated response that the cell engages to repair the DNA lesion following damage. This failure would allow the mutation to be fixed and transmitted along the cellular progeny. After a number of mutations occur, the cell would then transform. Mycoplasmas and certain other bacteria with similar DnaK may then be involved in the initiation of some cancers but not necessarily involved nor necessarily even be present in later stages. It is clearly of biological interest and potential therapeutic relevance to verify these findings in broader studies to understand the physical basis and the mechanism(s) responsible for reduced activities and levels of these critical cellular pathways. These studies may ultimately provide new preventive, diagnostic and therapeutic opportunities.

\section{Materials and Methods}

\subsection{Cloning of M. fermentans MF-I1 DnaK.}

The DnaK gene was synthesized at a commercial facility (Blue Heron Biotech, Bothell, WA). The nucleotide sequence was deduced from the genome sequence of M. fermentans. (MF-I1 strain) (ATFG00000000). Two tryptophan codons in the Mycoplasma sequence that are read as stop codon in eukaryotic cells were replaced by two tryptophan-codifying codons (G->A in positions 613 and 634). The TAG stop codon of the DnaK gene was deleted to make a fusion protein with the V5-(His) 5 tag in the vector and cloned into the pcDNA 3.1 Directional/V5-His TOPO vector. After selection, clones were 
screened for the presence of the DnaK insert and the insert was sequenced to verify proper nucleotide composition [107]. DnaK is under the CMV promoter and it is expressed in HCT116 cells [107].

\subsection{Expression and Purification of M. fermentans MF-I1 DnaK}

Recombinant DnaK-V5 was obtained as previously described [107] briefly, MF-I1 DnaK sequence was inserted into a cloning vector, followed by the transformation and expression of the protein, subculture into TB/LB with Kanamycin, fractionation and purification (Biomatik USA, Wilmington, DE). After purification, the protein was extensively dialyzed against PBS1X, pH 7.4. Coomassie blue-stained SDS-PAGE ( $>85 \%$ ) was used to determine purity. Aliquots of the protein were kept at $-80{ }^{\circ} \mathrm{C}$ after reconstitution. Particular care was taken to avoid frequent freeze-thaws.

\subsection{Transfection Assay}

HCT116 cells (ATCC) were plated in 6-well plates at concentrations of 150,000 cells/well. After 24 $\mathrm{h}$, cells were transfected with an expression vector containing M. fermentans MF-I1 DnaK. After about $32 \mathrm{~h}$, cells were treated with $\mathrm{H}_{2} \mathrm{O}_{2}(750 \mu \mathrm{M})$ for the indicated time. Cells were then harvested, lysed in cell lysis buffer in the presence of protease inhibitors, subjected to SDS-PAGE $6 \%$, and analyzed by Western blot. Anti-PAR monoclonal antibody $(10 \mathrm{H})$ was from Millipore Sigma. MW are indicated.

\subsection{Quantification of Protein PARylation}

Following developing with BioRad (ChemiDoc Imaging System), digital images were analyzed with ImageJ for pixel quantitation representing the PARylation of proteins $>150 \mathrm{KDa}$ or between 100-150 KDa. The data are expressed as percentage of control, not transfected cells treated for $20 \mathrm{~min}$.

\subsection{Confocal Microscopy Assay}

Cells (PC3 or HeLA) were treated with DnaK-V5 protein. A mouse monoclonal antibody, anti-V5, was used for primary labeling, and a FITC fluoresce-labeled antibody was used for secondary labeling. Control samples have been stained with the same conditions described above in the absence of DnaK-V5. Confocal images of cell-associated fluorescence were acquired on Zeiss LSM800 confocal system (Carl Zeiss Microscopy, Germany). Zen Blue software was used to generate original images and Z-stacking option (1-micron size of sample slices) was utilized in order to achieve better information about mapping the protein areas of interest in three dimensions. All the parameters used in fluorescence microscopy were consistent in each experiment, including the laser excitation power, detector and offset gain.

Author Contributions: F.B. conceived, designed and performed the experiment presented in Figure 1. S.K. helped with the experiments presented in Figure 1. F.C. and O.S.L. performed and designed the experiments presented in Figure 2A,B. F.B., F.C., O.S.L., S.C., S.K., A.M., R.C.G. and D.Z. wrote sections of this manuscript. R.C.G. and D.Z. coordinated and supervised research. All authors read and approved the submitted version of the manuscript.

Funding: This work was supported by IHV's internal funding.

Conflicts of Interest: The authors declare no conflict of interest.

\section{References}

1. Razin, S. Peculiar properties of mycoplasmas: The smallest self-replicating prokaryotes. FEMS Microbiol. Lett. 1992, 100, 423-431. [CrossRef] [PubMed]

2. Kornspan, J.D.; Rottem, S. The Phospholipid Profile of Mycoplasmas. J. Lipids 2012, 2012, 640762. [CrossRef] [PubMed]

3. Liu, Y.C.; Lin, I.H.; Chung, W.J.; Hu, W.S.; Ng, W.V.; Lu, C.Y.; Huang, T.Y.; Shu, H.W.; Hsiao, K.J.; Tsai, S.F.; et al. Proteomics Characterization of Cytoplasmic and Lipid-Associated Membrane Proteins of Human Pathogen Mycoplasma fermentans M64. PLoS ONE 2012, 7, e35304. [CrossRef] [PubMed] 
4. Regula, J.T.; Boguth, G.; Gorg, A.; Hegermann, J.; Mayer, F.; Frank, R.; Herrmann. Defining the mycoplasma 'cytoskeleton': The protein composition of the Triton X-100 insoluble fraction of the bacterium Mycoplasma pneumoniae determined by 2-D gel electrophoresis and mass spectrometry. Microbiology 2001, 147, 1045-1057. [CrossRef] [PubMed]

5. Benedetti, F.; Krishnan, S.; Cocchi, F.; Tettelin, H.; Gallo, R.C.; Zella, D.; Curreli, S. Proteome analysis of Mycoplasma fermentans cultured under aerobic and anaerobic conditions. Transl. Med. Commun. 2019, 4, 1-14. [CrossRef]

6. Razin, S.; Yogev, D.; Naot, Y. Molecular Biology and Pathogenicity of Mycoplasmas. Microbiol. Mol. Boil. Rev. 1998, 62, 1094-1156. [CrossRef]

7. Lo, S.C.; Hayes, M.M.; Kotani, H.; Pierce, P.F.; Wear, D.J.; Newton, P.B., 3rd; Tully, J.G.; Shih, J.W. Adhesion onto and invasion into mammalian cells by mycoplasma penetrans: A newly isolated mycoplasma from patients with AIDS. Mod. Pathol. 1993, 6, 276-280.

8. Yavlovich, A.; Tarshis, M.; Rottem, S. Internalization and intracellular survival of Mycoplasma pneumoniae by non-phagocytic cells. FEMS Microbiol. Lett. 2004, 233, 241-246. [CrossRef]

9. Shibata, K.; Hasebe, A.; Into, T.; Yamada, M.; Watanabe, T. The N-terminal lipopeptide of a 44-kDa membrane-bound lipoprotein of Mycoplasma salivarium is responsible for the expression of intercellular adhesion molecule- 1 on the cell surface of normal human gingival fibroblasts. J. Immunol. 2000, 165, 6538-6544. [CrossRef]

10. Baseman, J.B.; Lange, M.; Criscimagna, N.L.; Giron, J.A.; Thomas, C.A. Interplay between mycoplasmas and host target cells. Microb. Pathog. 1995, 19, 105-116. [CrossRef]

11. Rottem, S. Interaction of Mycoplasmas With Host Cells. Physiol. Rev. 2003, 83, 417-432. [CrossRef] [PubMed]

12. Kawahito, Y.; Ichinose, S.; Sano, H.; Tsubouchi, Y.; Kohno, M.; Yoshikawa, T.; Tokunaga, D.; Hojo, T.; Harasawa, R.; Nakano, T.; et al. Mycoplasma fermentans glycolipid-antigen as a pathogen of rheumatoid arthritis. Biochem. Biophys. Res. Commun. 2008, 369, 561-566. [CrossRef] [PubMed]

13. Gilroy, C.B.; Keat, A.; Taylor-Robinson, D. The prevalence of Mycoplasma fermentans in patients with inflammatory arthritides. Rheumatol. 2001, 40, 1355-1358. [CrossRef] [PubMed]

14. Yanez, A.; Martinez-Ramos, A.; Calixto, T.; Gonzalez-Matus, F.J.; Rivera-Tapia, J.A.; Giono, S.; Gil, C.; Cedillo, L. Animal model of Mycoplasma fermentans respiratory infection. BMC Res. Notes 2013, 6, 9. [CrossRef]

15. Tully, J.G.; Taylor-Robinson, D.; Cole, R.M.; Rose, D.L. A newly discovered mycoplasma in the human urogenital tract. Lancet 1981, 317, 1288-1291. [CrossRef]

16. He, J.; Liu, M.; Ye, Z.; Tan, T.; Liu, X.; You, X.; Zeng, Y.; Wu, Y. [Corrigendum] Insights into the pathogenesis of Mycoplasma pneumoniae (Review). Mol. Med. Rep. 2018, 17, 4155. [CrossRef]

17. Benedetti, F.; Curreli, S.; Krishnan, S.; Davinelli, S.; Cocchi, F.; Scapagnini, G.; Gallo, R.C.; Zella, D. Anti-inflammatory effects of H2S during acute bacterial infection: A review. J. Transl. Med. 2017, 15, 100. [CrossRef]

18. Browning, G.F.; Marenda, M.S.; Noormohammadi, A.H.; Markham, P.F. The central role of lipoproteins in the pathogenesis of mycoplasmoses. Veter Microbiol. 2011, 153, 44-50. [CrossRef]

19. Stuart, P.; Egan, R.M.; Woodward, J.G. Characterization of MHC Induction by Mycoplasma fermentans (Incognitus Strain). Cell. Immunol. 1993, 152, 261-270. [CrossRef]

20. D'Orazio, J.A.; Cole, B.C.; Stein-Streilein, J. Mycoplasma arthritidis mitogen up-regulates human NK cell activity. Infect. Immun. 1996, 64, 441-447. [CrossRef]

21. Matsumoto, M.; Nishiguchi, M.; Kikkawa, S.; Nishimura, H.; Nagasawa, S.; Seya, T. Structural and functional properties of complement-activating protein M161Ag, a Mycoplasma fermentans gene product that induces cytokine production by human monocytes. J. Boil. Chem. 1998, 273, 12407-12414. [CrossRef] [PubMed]

22. Seya, T.; Matsumoto, M. A lipoprotein family from Mycoplasma fermentans confers host immune activation through Toll-like receptor 2. Int. J. Biochem. Cell Boil. 2002, 34, 901-906. [CrossRef]

23. Takeda, K.; Takeuchi, O.; Akira, S. Recognition of lipopeptides by Toll-like receptors. J. Endotoxin Res. 2002, 8, 459-463. [CrossRef] [PubMed]

24. Pezzuto, A.; Stellato, M.; Catania, G.; Mazzara, C.; Tonini, S.; Caricato, M.; Crucitti, P.; Tonini, G. Short-term benefit of smoking cessation along with glycopirronium on lung function and respiratory symptoms in mild COPD patients: A retrospective study. J. Breath Res. 2018, 12, 046007. [CrossRef] [PubMed] 
25. Tuder, R.M.; Petrache, I. Pathogenesis of chronic obstructive pulmonary disease. J. Clin. Investig. 2012, 122, 2749-2755. [CrossRef] [PubMed]

26. Barnes, P.J. New anti-inflammatory targets for chronic obstructive pulmonary disease. Nat. Rev. Drug Discov. 2013, 12, 543-559. [CrossRef] [PubMed]

27. Varma-Basil, M.; Dwivedi, S.K.; Kumar, K.; Pathak, R.; Rastogi, R.; Thukral, S.S.; Shariff, M.; Vijayan, V.K.; Chhabra, S.K.; Chaudhary, R. Role of Mycoplasma pneumoniae infection in acute exacerbations of chronic obstructive pulmonary disease. J. Med. Microbiol. 2009, 58, 322-326. [CrossRef] [PubMed]

28. Beasley, V.; Joshi, P.V.; Singanayagam, A.; Molyneaux, P.L.; Johnston, S.L.; Mallia, P. Lung microbiology and exacerbations in COPD. Int. J. Chronic Obstr. Pulm. Dis. 2012, 7, 555-569.

29. Lieberman, D.; Lieberman, D.; Ben-Yaakov, M.; Shmarkov, O.; Gelfer, Y.; Varshavsky, R.; Ohana, B.; Lazarovich, Z.; Boldur, I. Serological evidence of Mycoplasma pneumoniae infection in acute exacerbation of COPD. Diagn. Microbiol. Infect. Dis. 2002, 44, 1-6. [CrossRef]

30. Diederen, B.M.W.; van der Valk, P.D.L.P.M.; Kluytmans, J.A.W.J.; Peeters, M.F.; Hendrix, R. The role of atypical respiratory pathogens in exacerbations of chronic obstructive pulmonary disease. Eur. Respir. J. 2007, 30, 240-244. [CrossRef]

31. Kariya, C.; Chu, H.W.; Huang, J.; Leitner, H.; Martin, R.J.; Day, B.J. Mycoplasma pneumoniae infection and environmental tobacco smoke inhibit lung glutathione adaptive responses and increase oxidative stress. Infect. Immun. 2008, 76, 4455-4462. [CrossRef] [PubMed]

32. Flores, R.E.; Brown, A.K.; Taus, L.; Khoury, J.; Glover, F.; Kami, K.; Sarangarajan, R.; Walshe, T.E.; Narain, N.R.; Kiebish, M.; et al. Mycoplasma infection and hypoxia initiate succinate accumulation and release in the VM-M3 cancer cells. Biochim. Biophys. Acta Bioenerg. 2018, 1859, 975-983. [CrossRef] [PubMed]

33. Papi, A.; Casoni, G.; Caramori, G.; Guzzinati, I.; Boschetto, P.; Ravenna, F.; Calia, N.; Petruzzelli, S.; Corbetta, L.; Cavallesco, G.; et al. COPD increases the risk of squamous histological subtype in smokers who develop non-small cell lung carcinoma. Thorax 2004, 59, 679-681. [CrossRef] [PubMed]

34. Young, R.P.; Hopkins, R.J. Link between COPD and lung cancer. Respir. Med. 2010, 104, 758-759. [CrossRef]

35. Young, R.P.; Duan, F.; Chiles, C.; Hopkins, R.J.; Gamble, G.D.; Greco, E.M.; Gatsonis, C.; Aberle, D. Airflow Limitation and Histology Shift in the National Lung Screening Trial. The NLST-ACRIN Cohort Substudy. Am. J. Respir. Crit. Care Med. 2015, 192, 1060-1067. [CrossRef]

36. Pezzuto, A.; Perrone, G.; Orlando, N.; Citarella, F.; Ciccozzi, M.; Scarlata, S.; Tonini, G.; Pezzuto, A. A close relationship between HIF-1-alpha expression and bone metastases in advanced NSCLC, a retrospective analysis. Oncotarget 2019, 10, 7071-7079.

37. Cimolai, N. Do mycoplasmas cause human cancer? Can. J. Microbiol. 2001, 47, 691-697. [CrossRef]

38. Rogers, M.B. Mycoplasma and cancer: In search of the link. Oncotarget 2011, 2, 271-273. [CrossRef]

39. Vogtmann, E.; Goedert, J.J. Epidemiologic studies of the human microbiome and cancer. Br. J. Cancer 2016, 114, 237-242. [CrossRef]

40. Reddel, R.R.; Salghetti, S.E.; Willey, J.C.; Ohnuki, Y.; Ke, Y.; Gerwin, B.I.; Lechner, J.F.; Harris, C.C. Development of tumorigenicity in simian virus 40-immortalized human bronchial epithelial cell lines. Cancer Res. 1993, 53, 985-991.

41. Choi, H.S.; Lee, H.M.; Kim, W.T.; Kim, M.K.; Chang, H.J.; .Lee, H.R.; Joh, J.W.; Kim, D.S.; Ryu, C.J. Detection of mycoplasma infection in circulating tumor cells in patients with hepatocellular carcinoma. Biochem. Biophys. Res. Commun. 2014, 446, 620-625. [CrossRef] [PubMed]

42. Patil, S.; Rao, R.S.; Raj, A.T. Role of Mycoplasma in the Initiation and Progression of Oral Cancer. J. Int. Oral Health 2015, 7, i-ii. [PubMed]

43. Namiki, K.; Goodison, S.; Porvasnik, S.; Allan, R.W.; Iczkowski, K.A.; Urbanek, C.; Reyes, L.; Sakamoto, N.; Rosser, C.J. Persistent exposure to Mycoplasma induces malignant transformation of human prostate cells. PLoS ONE 2009, 4, e6872. [CrossRef] [PubMed]

44. Barykova, Y.A.; Logunov, D.Y.; Shmarov, M.M.; Vinarov, A.Z.; Fiev, D.N.; Vinarova, N.A.; Rakovskaya, I.V.; Baker, P.S.; Shyshynova, I.; Stephenson, A.J.; et al. Association of Mycoplasma hominis infection with prostate cancer. Oncotarget 2011, 2, 289-297. [CrossRef]

45. Zhang, S.; Wear, D.J.; Lo, S. Mycoplasmal infections alter gene expression in cultured human prostatic and cervical epithelial cells. FEMS Immunol. Med. Microbiol. 2000, 27, 43-50. [CrossRef]

46. Zhang, S.; Tsai, S.; Lo, S.-C. Alteration of gene expression profiles during mycoplasma-induced malignant cell transformation. BMC Cancer 2006, 6, 116. [CrossRef] 
47. Afriat, R.; Horowitz, S.; Priel, E. Mycoplasma fermentans Inhibits the Activity of Cellular DNA Topoisomerase I by Activation of PARP1 and Alters the Efficacy of Its Anti-Cancer Inhibitor. PLoS ONE 2013, 8, e72377. [CrossRef]

48. Paton, G.R.; Jacobs, J.P.; Perkins, F.T. Chromosome Changes in Human Diploid-Cell Cultures Infected with Mycoplasma. Nature 1965, 207, 43-45. [CrossRef]

49. Tsai, S.; Wear, D.J.; Shih, J.W.; Lo, S.C. Mycoplasmas and oncogenesis: Persistent infection and multistage malignant transformation. Proc. Natl. Acad. Sci. USA 1995, 92, 10197-10201. [CrossRef]

50. Feng, S.H.; Tsai, S.; Rodriguez, J.; Lo, S.C. Mycoplasmal infections prevent apoptosis and induce malignant transformation of interleukin-3-dependent 32D hematopoietic cells. Mol. Cell Biol. 1999, 19, 7995-8002. [CrossRef]

51. Zhang, B.; Shih, J.W.; Wear, D.J.; Tsai, S.; Lo, S.C. High-level expression of H-ras and c-myc oncogenes in mycoplasma-mediated malignant cell transformation. Proc. Soc. Exp. Boil. Med. 1997, 214, 359-366. [CrossRef] [PubMed]

52. Logunov, D.Y.; Scheblyakov, D.V.; Zubkova, O.V.; Shmarov, M.M.; Rakovskaya, I.V.; Gurova, K.V.; Tararova, N.D.; Burdelya, L.G.; Naroditsky, B.S.; Ginzburg, A.L.; et al. Mycoplasma infection suppresses p53, activates NF-kappaB and cooperates with oncogenic Ras in rodent fibroblast transformation. Oncogene 2008, 27, 4521-4531. [CrossRef] [PubMed]

53. Mantovani, A. Molecular pathways linking inflammation and cancer. Curr. Mol. Med. 2010, 10, 369-373. [CrossRef] [PubMed]

54. Tilborghs, S.; Corthouts, J.; Verhoeven, Y.; Arias, D.; Rolfo, C.; Trinh, X.B.; van Dam, P.A. The role of Nuclear Factor-kappa B signaling in human cervical cancer. Crit. Rev. Oncol. 2017, 120, 141-150. [CrossRef]

55. Dolcet, X.; Llobet, D.; Pallares, J.; Matias-Guiu, X. NF-kB in development and progression of human cancer. Virchows Archiv 2005, 446, 475-482. [CrossRef]

56. Wachsman, J.T. DNA methylation and the association between genetic and epigenetic changes: Relation to carcinogenesis. Mutat. Res. Mol. Mech. Mutagen. 1997, 375, 1-8. [CrossRef]

57. Chernov, A.V.; Reyes, L.; Xu, Z.; Gonzalez, B.; Golovko, G.; Peterson, S.; Perucho, M.; Fofanov, Y.; Strongin, A.Y. Mycoplasma CG- and GATC-specific DNA methyltransferases selectively and efficiently methylate the host genome and alter the epigenetic landscape in human cells. Epigenetics 2015, 10, 303-318. [CrossRef]

58. Niller, H.H.; Masa, R.; Venkei, A.; Meszaros, S.; Minarovits, J. Pathogenic mechanisms of intracellular bacteria. Curr. Opin. Infect. Dis. 2017, 30,1-315. [CrossRef]

59. Chernov, A.V.; Reyes, L.; Peterson, S.; Strongin, A.Y. Depletion of CG-Specific Methylation in Mycoplasma hyorhinis Genomic DNA after Host Cell Invasion. PLoS ONE 2015, 10, e0142529. [CrossRef]

60. Pacis, A.; Tailleux, L.; Morin, A.M.; Lambourne, J.; MacIsaac, J.L.; Yotova, V.; Dumaine, A.; Danckaert, A.; Luca, F.; Grenier, J.C.; et al. Bacterial infection remodels the DNA methylation landscape of human dendritic cells. Genome Res. 2015, 25, 1801-1811. [CrossRef]

61. Wojciechowski, M.; Czapinska, H.; Bochtler, M. CpG underrepresentation and the bacterial CpG-specific DNA methyltransferase M.MpeI. Proc. Natl. Acad. Sci. USA 2013, 110, 105-110. [CrossRef] [PubMed]

62. Jiang, S.; Zhang, S.; Langenfeld, J.; Lo, S.C.; Rogers, M.B. Mycoplasma infection transforms normal lung cells and induces bone morphogenetic protein 2 expression by post-transcriptional mechanisms. J. Cell. Biochem. 2008, 104, 580-594. [CrossRef] [PubMed]

63. Langenfeld, E.M.; Bojnowski, J.; Perone, J.; Langenfeld, J. Expression of bone morphogenetic proteins in human lung carcinomas. Ann. Thorac. Surg. 2005, 80, 1028-1032. [CrossRef] [PubMed]

64. Liu, X.; Rong, Z.; Shou, C. Mycoplasma hyorhinis infection promotes gastric cancer cell motility via beta-catenin signaling. Cancer Med. 2019, 8, 5301-5312. [CrossRef]

65. Kim, M.K.; Shin, S.J.; Lee, H.M.; Choi, H.S.; Jeong, J.; Kim, H.; Paik, S.S.; Kim, M.; Choi, D.; Ryu, C.J. Mycoplasma infection promotes tumor progression via interaction of the mycoplasmal protein p37 and epithelial cell adhesion molecule in hepatocellular carcinoma. Cancer Lett. 2019, 454, 44-52. [CrossRef]

66. Ketcham, C.M.; Anai, S.; Reutzel, R.; Sheng, S.; Schuster, S.M.; Brenes, R.B.; Agbandje-McKenna, M.; McKenna, R.; Rosser, C.J.; Boehlein, S.K. p37 induces tumor invasiveness. Mol. Cancer Ther. 2005, 4, 1031-1038. [CrossRef]

67. Goodison, S.; Nakamura, K.; Iczkowski, K.A.; Anai, S.; Boehlein, S.K.; Rosser, C.J. Exogenous mycoplasmal p37 protein alters gene expression, growth and morphology of prostate cancer cells. Cytogenet. Genome Res. 2007, 118, 204-213. [CrossRef] 
68. Miller, C.J.; Kassem, H.S.; Pepper, S.D.; Hey, Y.; Ward, T.H.; Margison, G.P. Mycoplasma infection significantly alters microarray gene expression profiles. Biotechniques 2003, 35, 812-814. [CrossRef]

69. Yang, J.; Hooper, W.C.; Phillips, D.J.; Talkington, D.F. Regulation of proinflammatory cytokines in human lung epithelial cells infected with Mycoplasma pneumoniae. Infect. Immun. 2002, 70, 3649-3655. [CrossRef]

70. Huang, S.; Li, J.Y.; Wu, J.; Meng, L.; Shou, C.C. Mycoplasma infections and different human carcinomas. World J. Gastroenterol. 2001, 7, 266-269. [CrossRef]

71. Pehlivan, M.; Pehlivan, S.; Onay, H.; Koyuncuoglu, M.; Kirkali, Z. Can mycoplasma-mediated oncogenesis be responsible for formation of conventional renal cell carcinoma? Urology 2005, 65, 411-414. [CrossRef] [PubMed]

72. Chang, A.H.; Parsonnet, J. Role of Bacteria in Oncogenesis. Clin. Microbiol. Rev. 2010, 23, 837-857. [CrossRef] [PubMed]

73. Yow, M.A.; Tabrizi, S.N.; Severi, G.; Bolton, D.M.; Pedersen, J.; Longano, A.; Garland, S.M.; Southey, M.C.; Giles, G.G. Detection of infectious organisms in archival prostate cancer tissues. BMC Cancer 2014, 14, 579. [CrossRef] [PubMed]

74. Saibil, H. Chaperone machines for protein folding, unfolding and disaggregation. Nat. Rev. Mol. Cell Boil. 2013, 14, 630-642. [CrossRef]

75. Radons, J. The human HSP70 family of chaperones: Where do we stand? Cell Stress Chaperon- 2016, 21, 379-404. [CrossRef]

76. Jäättelä, M. Over-expression of hsp70 confers tumorigenicity to mouse fibrosarcoma cells. Int. J. Cancer 1995, 60, 689-693. [CrossRef]

77. Seo, J.-S.; Park, Y.-M.; Kim, J.-I.; Shim, E.-H.; Kim, C.-W.; Jang, J.-J.; Kim, S.-H.; Lee, W.-H. T Cell Lymphoma in Transgenic Mice Expressing the HumanHsp70Gene. Biochem. Biophys. Res. Commun. 1996, 218, 582-587. [CrossRef]

78. Kaur, J.; Ralhan, R. Induction of apoptosis by abrogation of HSP70 expression in human oral cancer cells. Int. J. Cancer 2000, 85, 1-5. [CrossRef]

79. Calloni, G.; Chen, T.; Schermann, S.M.; Chang, H.C.; Genevaux, P.; Agostini, F.; Tartaglia, G.G.; Hayer-Hartl, M.; Hartl, F.U. DnaK functions as a central hub in the E. coli chaperone network. Cell Rep. 2012, 1, 251-264. [CrossRef]

80. Nunes, J.M.; Mayer-Hartl, M.; Hartl, F.U.; Müller, D.J. Action of the Hsp70 chaperone system observed with single proteins. Nat. Commun. 2015, 6, 6307. [CrossRef]

81. Sterrenberg, J.N.; Blatch, G.L.; Edkins, A.L. Human DNAJ in cancer and stem cells. Cancer Lett. 2011, 312, 129-142. [CrossRef] [PubMed]

82. Kampinga, H.H.; Craig, E.A. The HSP70 chaperone machinery: J proteins as drivers of functional specificity. Nat. Rev. Mol. Cell Boil. 2010, 11, 579-592. [CrossRef] [PubMed]

83. Clerico, E.M.; Tilitsky, J.M.; Meng, W.; Gierasch, L.M. How hsp70 molecular machines interact with their substrates to mediate diverse physiological functions. J. Mol. Boil. 2015, 427, 1575-1588. [CrossRef] [PubMed]

84. Kampinga, H.H.; Hageman, J.; Vos, M.J.; Kubota, H.; Tanguay, R.M.; Bruford, E.A.; Cheetham, M.E.; Chen, B.; Hightower, L.E. Guidelines for the nomenclature of the human heat shock proteins. Cell Stress Chaperones 2009, 14, 105-111. [CrossRef]

85. Tang, D.; Khaleque, M.A.; Jones, E.L.; Theriault, J.R.; Li, C.; Wong, W.H.; Stevenson, M.A.; Calderwood, S.K. Expression of heat shock proteins and heat shock protein messenger ribonucleic acid in human prostate carcinoma in vitro and in tumors in vivo. Cell Stress Chaperones 2005, 10, 46-58. [CrossRef]

86. Syken, J.; De-Medina, T.; Münger, K. TID1, a human homolog of the Drosophila tumor suppressor 1(2)tid, encodes two mitochondrial modulators of apoptosis with opposing functions. Proc. Natl. Acad. Sci. USA 1999, 96, 8499-8504. [CrossRef]

87. Cheng, H.; Cenciarelli, C.; Nelkin, G.; Tsan, R.; Fan, D.; Cheng-Mayer, C.; Fidler, I.J. Molecular mechanism of hTid-1, the human homolog of Drosophila tumor suppressor 1(2)Tid, in the regulation of NF-kappaB activity and suppression of tumor growth. Mol. Cell Biol. 2005, 25, 44-59. [CrossRef]

88. Kim, S.-W.; Hayashi, M.; Lo, J.-F.; Fearns, C.; Xiang, R.; Lazennec, G.; Yang, Y.; Lee, J.-D. Tid1 Negatively Regulates the Migratory Potential of Cancer Cells by Inhibiting the Production of Interleukin-8. Cancer Res. 2005, 65, 8784-8791. [CrossRef] 
89. Kim, S.W.; Chao, T.H.; Xiang, R.; Lo, J.F.; Campbell, M.J.; Fearns, C.; Lee, J.D. Tid1, the human homologue of a Drosophila tumor suppressor, reduces the malignant activity of ErbB-2 in carcinoma cells. Cancer Res. 2004, 64, 7732-7739. [CrossRef]

90. Copeland, E.; Balgobin, S.; Lee, C.M.; Rozakis-Adcock, M. hTID-1 defines a novel regulator of c-Met Receptor signaling in renal cell carcinomas. Oncogene 2011, 30, 2252-2263. [CrossRef]

91. Dhennin-Duthille, I.; Nyga, R.; Yahiaoui, S.; Gouilleux-Gruart, V.; Regnier, A.; Lassoued, K.; Gouilleux, F. The tumor suppressor hTid1 inhibits STAT5b activity via functional interaction. J. Biol. Chem. 2011, 286, 5034-5042. [CrossRef] [PubMed]

92. Tsai, M.F.; Wang, C.C.; Chang, G.C.; Chen, C.Y.; Chen, H.Y.; Cheng, C.L.; Yang, Y.P.; Wu, C.Y.; Shih, F.Y.; Liu, C.C.; et al. A new tumor suppressor DnaJ-like heat shock protein, HLJ1, and survival of patients with non-small-cell lung carcinoma. J. Natl. Cancer Inst. 2006, 98, 825-838. [CrossRef] [PubMed]

93. Lin, S.Y.; Hsueh, C.M.; Yu, S.L.; Su, C.C.; Shum, W.Y.; Yeh, K.C.; Chang, G.C.; Chen, J.J. HLJ1 is a novel caspase-3 substrate and its expression enhances UV-induced apoptosis in non-small cell lung carcinoma. Nucleic Acids Res. 2010, 38, 6148-6158. [CrossRef] [PubMed]

94. Chen, C.H.; Lin, H.; Chuang, S.M.; Lin, S.Y.; Chen, J.J. Acidic stress facilitates tyrosine phosphorylation of HLJ1 to associate with actin cytoskeleton in lung cancer cells. Exp. Cell Res. 2010, 316, 2910-2921. [CrossRef] [PubMed]

95. Mitra, A.; Fillmore, R.A.; Metge, B.J.; Rajesh, M.; Xi, Y.; King, J.; Ju, J.; Pannell, L.; Shevde, L.A.; Samant, R.S. Large isoform of MRJ (DNAJB6) reduces malignant activity of breast cancer. Breast Cancer Res. 2008, 10, R22. [CrossRef]

96. Mitra, A.; Menezes, M.E.; Shevde, L.A.; Samant, R.S. DNAJB6 induces degradation of beta-catenin and causes partial reversal of mesenchymal phenotype. J. Biol. Chem. 2010, 285, 24686-24694. [CrossRef]

97. Wen, K.W.; Damania, B. Hsp90 and Hsp40/Erdj3 are required for the expression and anti-apoptotic function of KSHV K1. Oncogene 2010, 29, 3532-3544. [CrossRef]

98. Thomas, C.G.; Spyrou, G. ERdj5 Sensitizes Neuroblastoma Cells to Endoplasmic Reticulum Stress-induced Apoptosis. J. Boil. Chem. 2009, 284, 6282-6290. [CrossRef]

99. Lindsey, J.; Lusher, M.; Strathdee, G.; Brown, R.; Gilbertson, R.; Bailey, S.; Ellison, D.; Clifford, S. Epigenetic inactivation ofMCJ (DNAJD1) in malignant paediatric brain tumours. International journal of cancer. Int. J. Cancer 2006, 118, 346-352. [CrossRef]

100. Shridhar, V.; Bible, K.C.; Staub, J.; Avula, R.; Lee, Y.K.; Kalli, K.; Huang, H.; Hartmann, L.C.; Kaufmann, S.H.; Smith, D.I. Loss of expression of a new member of the DNAJ protein family confers resistance to chemotherapeutic agents used in the treatment of ovarian cancer. Cancer Res. 2001, 61, 4258-4265.

101. Hatle, K.M.; Neveu, W.; Dienz, O.; Rymarchyk, S.; Barrantes, R.; Hale, S.; Farley, N.; Lounsbury, K.M.; Bond, J.P.; Taatjes, D.; et al. Methylation-controlled J protein promotes c-Jun degradation to prevent ABCB1 transporter expression. Mol. Cell. Boil. 2007, 27, 2952-2966. [CrossRef] [PubMed]

102. Zzaman, S.; Reddy, J.M.; Bastia, D. The DnaK-DnaJ-GrpE chaperone system activates inert wild type pi initiator protein of R6K into a form active in replication initiation. J. Biol. Chem. 2004, 279, 50886-50894. [CrossRef] [PubMed]

103. Bosma, G.C.; Custer, R.P.; Bosma, M.J. A severe combined immunodeficiency mutation in the mouse. Nature 1983, 301, 527-530. [CrossRef] [PubMed]

104. Kirchgessner, C.U.; Patil, C.K.; Evans, J.W.; Cuomo, C.A.; Fried, L.M.; Carter, T.; Oettinger, M.A.; Brown, J.M. DNA-Dependent Kinase (p350) as a Candidate Gene for the Murine SCID Defect. Science 1995, 267, 1178-1183. [CrossRef]

105. Gurley, K.E.; Vo, K.; Kemp, C.J. DNA Double-Strand Breaks, p53, and Apoptosis during Lymphomagenesis in scid/scid Mice. Cancer Res. 1998, 58, 3111-3115.

106. Nacht, M.; Strasser, A.; Chan, Y.R.; Harris, A.W.; Schlissel, M.; Bronson, R.T.; Jacks, T. Mutations in the p53 and SCID genes cooperate in tumorigenesis. Genes Dev. 1996, 10, 2055-2066. [CrossRef]

107. Zella, D.; Curreli, S.; Benedetti, F.; Krishnan, S.; Cocchi, F.; Latinovic, O.S.; Denaro, F.; Romerio, F.; Djavani, M.; Charurat, M.E.; et al. Mycoplasma promotes malignant transformation in vivo, and its DnaK, a bacterial chaperone protein, has broad oncogenic properties. Proc. Natl. Acad. Sci. USA 2018, 115, E12005-E12014. [CrossRef]

108. Olivier, M.; Hollstein, M.; Hainaut, P. TP53 mutations in human cancers: Origins, consequences, and clinical use. Cold Spring Harb. Perspect. Biol. 2010, 2, a001008. [CrossRef] 
109. Robles, A.I.; Harris, C.C. Clinical outcomes and correlates of TP53 mutations and cancer. Cold Spring Harb. Perspect. Biol. 2010, 2, a001016. [CrossRef]

110. Vogelstein, B.; Lane, D.; Levine, A.J. Surfing the p53 network. Nature 2000, 408, 307-310. [CrossRef]

111. Malkin, D.; Li, F.P.; Strong, L.C.; Fraumeni, J.F., Jr.; Nelson, C.E.; Kim, D.H.; Kassel, J.; Gryka, M.A.; Bischoff, F.Z.; Tainsky, M.A.; et al. Germ line p53 mutations in a familial syndrome of breast cancer, sarcomas, and other neoplasms. Science 1990, 250, 1233-1238. [CrossRef]

112. Donehower, L.A.; Harvey, M.; Slagle, B.L.; McArthur, M.J.; Montgomery, C.A., Jr.; Butel, J.S.; Bradley, A. Mice deficient for p53 are developmentally normal but susceptible to spontaneous tumours. Nature 1992, 356, 215-221. [CrossRef]

113. Yuan, J.; Luo, K.; Zhang, L.; Cheville, J.C.; Lou, Z. USP10 regulates p53 localization and stability by deubiquitinating p53. Cell 2010, 140, 384-396. [CrossRef]

114. Jochemsen, A.G.; Shiloh, Y. USP10: Friend and foe. Cell 2010, 140, 308-310. [CrossRef]

115. Liu, J.; Xia, H.; Kim, M.; Xu, L.; Li, Y.; Zhang, L.; Cai, Y.; Norberg, H.V.; Zhang, T.; Furuya, T.; et al. Beclin1 controls the levels of p53 by regulating the deubiquitination activity of USP10 and USP13. Cell 2011, 147, 223-234. [CrossRef]

116. Bai, P. Biology of Poly(ADP-Ribose) Polymerases: The Factotums of Cell Maintenance. Mol. Cell 2015, 58, 947-958. [CrossRef]

117. Godon, C.; Cordelieres, F.P.; Biard, D.; Giocanti, N.; Megnin-Chanet, F.; Hall, J.; Favaudon, V. PARP inhibition versus PARP-1 silencing: Different outcomes in terms of single-strand break repair and radiation susceptibility. Nucleic Acids Res. 2008, 36, 4454-4464. [CrossRef]

118. Schultz, N.; Lopez, E.; Saleh-Gohari, N.; Helleday, T. Poly(ADP-ribose) polymerase (PARP-1) has a controlling role in homologous recombination. Nucleic Acids Res. 2003, 31, 4959-4964. [CrossRef]

119. Langelier, M.-F.; Planck, J.L.; Roy, S.; Pascal, J.M. Structural Basis for DNA Damage-Dependent Poly(ADP-ribosyl)ation by Human PARP-1. Science 2012, 336, 728-732. [CrossRef]

120. Amé, J.-C.; Spenlehauer, C.; De Murcia, G. The PARP superfamily. BioEssays 2004, 26, 882-893. [CrossRef]

121. Schreiber, V.; Dantzer, F.; Ame, J.C.; de Murcia, G. Poly(ADP-ribose): Novel functions for an old molecule. Nat. Rev. Mol. Cell Boil. 2006, 7, 517-528. [CrossRef] [PubMed]

122. De Murcia, J.M.; Niedergang, C.; Trucco, C.; Ricoul, M.; Dutrillaux, B.; Mark, M.; Oliver, F.J.; Masson, M.; Dierich, A.; LeMeur, M.; et al. Requirement of poly(ADP-ribose) polymerase in recovery from DNA damage in mice and in cells. Proc. Natl. Acad. Sci. USA 1997, 94, 7303-7307. [CrossRef] [PubMed]

123. Wang, Z.Q.; Stingl, L.; Morrison, C.; Jantsch, M.; Los, M.; Schulze-Osthoff, K.; Wagner, E.F. PARP is important for genomic stability but dispensable in apoptosis. Genome Res. 1997, 11, 2347-2358. [CrossRef] [PubMed]

124. d'Adda di Fagagna, F.; Hande, M.P.; Tong, W.M.; Lansdorp, P.M.; Wang, Z.Q.; Jackson, S.P. Functions of poly(ADP-ribose) polymerase in controlling telomere length and chromosomal stability. Nat. Genet. 1999, 23, 76-80. [CrossRef]

125. Morrison, C.; Smith, G.C.M.; Stingl, L.; Jackson, S.P.; Wagner, E.F.; Wang, Z.-Q. Genetic interaction between PARP and DNA-PK in V(D)J recombination and tumorigenesis. Nat. Genet. 1997, 17, 479. [CrossRef]

126. Coskun, E.; Tuna, G.; Jaruga, P.; Tona, A.; Erdem, O.; Dizdaroglu, M. Identification and quantification of DNA repair protein poly(ADP ribose) polymerase 1 (PARP1) in human tissues and cultured cells by liquid chromatography/isotope-dilution tandem mass spectrometry. DNA Repair 2019, 75, 48-59. [CrossRef]

127. Ludwig, A.; Behnke, B.; Holtlund, J.; Hilz, H. Immunoquantitation and size determination of intrinsic poly(ADP-ribose) polymerase from acid precipitates. An analysis of the in vivo status in mammalian species and in lower eukaryotes. J. Biol. Chem. 1988, 263, 6993-6999.

128. Lindahl, T.; Satoh, M.S.; Poirier, G.G.; Klungland, A. Post-translational modification of poly(ADP-ribose) polymerase induced by DNA strand breaks. Trends Biochem. Sci. 1995, 20, 405-411. [CrossRef]

129. Filippini, G.; Griffin, S.; Uhr, M.; Eppenberger, H.; Bonilla, J.; Cavalli, F.; Soldati, G. A novel flow cytometric method for the quantification of p53 gene expression. Cytometry 1998, 31, 180-186. [CrossRef]

130. Costa, T.R.D.; Felisberto-Rodrigues, C.; Meir, A.; Prevost, M.S.; Redzej, A.; Trokter, M.; Waksman, G. Secretion systems in Gram-negative bacteria: Structural and mechanistic insights. Nat. Rev. Microbiol. 2015, 13, 343. [CrossRef]

131. Holland, I.B. Translocation of bacterial proteins-An overview. Biochim. Biophys. Acta 2004, 1694, 5-16. [CrossRef] [PubMed] 
132. Carrió, M.M.; Villaverde, A. Localization of Chaperones DnaK and GroEL in Bacterial Inclusion Bodies. J. Bacteriol. 2005, 187, 3599-3601. [CrossRef] [PubMed]

133. Vega, V.L.; Rodríguez-Silva, M.; Frey, T.; Gehrmann, M.; Diaz, J.C.; Steinem, C.; Multhoff, G.; Arispe, N.; De Maio, A. Hsp70 Translocates into the Plasma Membrane after Stress and Is Released into the Extracellular Environment in a Membrane-Associated Form that Activates Macrophages. J. Immunol. 2008, 180, 4299-4307. [CrossRef] [PubMed]

134. Mambula, S.S.; Stevenson, M.A.; Ogawa, K.; Calderwood, S.K. Mechanisms for Hsp70 secretion: Crossing membranes without a leader. Methods 2007, 43, 168-175. [CrossRef] [PubMed]

135. Thériault, J.R.; Adachi, H.; Calderwood, S.K. Role of scavenger receptors in the binding and internalization of heat shock protein 70. J. Immunol. 2006, 177, 8604-8611. [CrossRef] [PubMed]

136. Bendtsen, J.D.; Kiemer, L.; Fausbøll, A.; Brunak, S. Non-classical protein secretion in bacteria. BMC Microbiol. 2005, 5, 58. [CrossRef]

137. Warren, J.R.; Marshall, B. Unidentified curved bacilli on gastric epithelium in active chronic gastritis. Lancet 1983, 321, 1273-1275.

138. Yu, T.; Guo, F.; Yu, Y.; Sun, T.; Ma, D.; Han, J.; Qian, Y.; Kryczek, I.; Sun, D.; Nagarsheth, N.; et al. Fusobacterium nucleatum Promotes Chemoresistance to Colorectal Cancer by Modulating Autophagy. Cell 2017, 170, 548-563.e16. [CrossRef]

139. Bullman, S.; Pedamallu, C.S.; Sicinska, E.; Clancy, T.E.; Zhang, X.; Cai, D.; Neuberg, D.; Huang, K.; Guevara, F.; Nelson, T.; et al. Analysis of Fusobacterium persistence and antibiotic response in colorectal cancer. Science 2017, 358, 1443-1448. [CrossRef]

140. Ahn, J.; Sinha, R.; Pei, Z.; Dominianni, C.; Wu, J.; Shi, J.; Goedert, J.J.; Hayes, R.B.; Yang, L. Human Gut Microbiome and Risk for Colorectal Cancer. J. Natl. Cancer Inst. 2013, 105, 1907-1911. [CrossRef]

141. Eklöf, V.; Löfgren-Burström, A.; Zingmark, C.; Edin, S.; Larsson, P.; Karling, P.; Alexeyev, O.; Rutegård, J.; Wikberg, M.L.; Palmqvist, R. Cancer-associated fecal microbial markers in colorectal cancer detection. Int. J. Cancer 2017, 141, 2528-2536. [CrossRef] [PubMed]

142. Li, Y.Y.; Ge, Q.X.; Cao, J.; Zhou, Y.J.; Du, Y.L.; Shen, B.; Wan, Y.J.; Nie, Y.Q. Association of Fusobacterium nucleatum infection with colorectal cancer in Chinese patients. World J. Gastroenterol. 2016, 22, 3227-3233. [CrossRef] [PubMed]

143. Shang, F.-M.; Liu, H.-L. Fusobacterium nucleatum and colorectal cancer: A review. World J. Gastrointest. Oncol. 2018, 10, 71-81. [CrossRef] [PubMed]

144. Barukčić, I. Fusobacterium nucleatum-The Cause of Human Colorectal Cancer. J. Biosci. Med. 2018, 6, 31-69.

145. Buti, L.; Spooner, E.; Van der Veen, A.G.; Rappuoli, R.; Covacci, A.; Ploegh, H.L. Helicobacter pylori cytotoxin-associated gene A (CagA) subverts the apoptosis-stimulating protein of p53 (ASPP2) tumor suppressor pathway of the host. Proc. Natl. Acad. Sci. USA 2011, 108, 9238-9243. [CrossRef]

146. Kaplan-Turkoz, B.; Jimenez-Soto, L.F.; Dian, C.; Ertl, C.; Remaut, H.; Louche, A.; Tosi, T.; Haas, R.; Terradot, L. Structural insights into Helicobacter pylori oncoprotein CagA interaction with beta1 integrin. Proc. Natl. Acad. Sci. USA 2012, 109, 14640-14645. [CrossRef]

147. Pezzuto, A.; Citarella, F.; Croghan, I.; Tonini, G. The effects of cigarette smoking extracts on cell cycle and tumor spread: Novel evidence. Future Sci. OA 2019, 5, FSO394. [CrossRef]

(C) 2020 by the authors. Licensee MDPI, Basel, Switzerland. This article is an open access article distributed under the terms and conditions of the Creative Commons Attribution (CC BY) license (http://creativecommons.org/licenses/by/4.0/). 